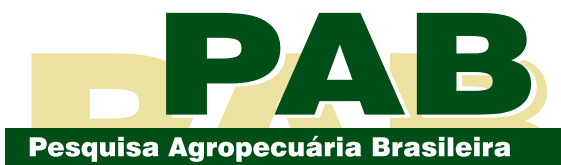

ISSN 1678-3921

Journal homepage: www.embrapa.br/pab

For manuscript submission and journal contents, access: www.scielo.br/pab

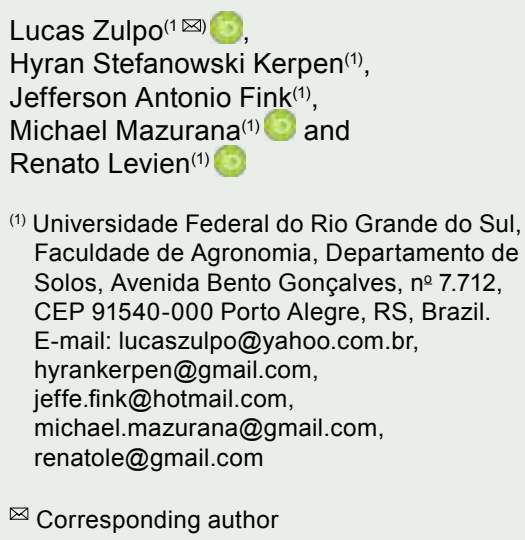

\section{Thermo-physical-hydraulic variables in a no-tillage system related to wheeled traffic and furrow-opening mechanisms}

\begin{abstract}
The objective of this work was to evaluate the impact of different furrow-opening mechanisms on soil physical characteristics, such as mobilization, porosity, bulk density, and the dynamics of water content and temperature in the sowing groove, as well as the influence of wheeled traffic and of these variables on corn (Zea mays) productivity. The experiment was conducted at the agronomic experimental station of Universidade Federal do Rio Grande do Sul on a Argissolo Vermelho (red Ultisol). Treatments consisted of three winter cover crops and of two types of furrow-opening mechanisms for fertilization (shank and disk), with or without tractor traffic. Corn was planted as the summer crop, and soil mobilization in the sowing groove, soil temperature and moisture content during the crop cycle, and soil physical conditions, such as bulk density and porosity, were evaluated. Tractor traffic and the type of furrow-opening mechanism used did not affect significantly soil temperature and moisture content during the development of the corn crop; however, significant differences were observed in grain productivity and soil mobilization, bulk density, and porosity.
\end{abstract}

Index terms: Zea mays, no-tillage system, furrow-opening mechanisms, soil compaction, soil temperature.

\section{Variáveis termo-físico-hídricas em semeadura direta relacionadas com tráfego de rodados e mecanismos sulcadores de fertilizante}

Resumo - O objetivo deste trabalho foi avaliar o impacto do uso de sulcadores de fertilizantes nas características físicas do solo, como mobilização, porosidade, densidade, e dinâmica do teor de água e da temperatura no sulco de semeadura, bem como a influência do tráfego do rodado do trator e dessas variáveis na produtividade do milho (Zea mays). O experimento foi conduzido na estação experimental agronômica da Universidade Federal do Rio Grande do Sul sobre um Argissolo Vermelho. Os tratamentos consistiram de três coberturas de inverno e dois sulcadores de fertilizante (haste e disco), com ou sem tráfego dos rodados do trator. O milho foi plantado como cultura de verão, tendo-se avaliado a mobilização no sulco de semeadura, a temperatura e a umidade do solo durante o ciclo da cultura, e as condições físicas do solo, como densidade e porosidade. O tráfego de rodados e os tipos de mecanismos sulcadores não afetaram significativamente a temperatura e a umidade do solo durante o desenvolvimento da cultura do milho; contudo, foram observadas diferenças significativas na produtividade de grãos e na mobilização, na densidade e na porosidade do solo.

Termos para indexação: Zea mays, sistema de semeadura direta, mecanismos sulcadores, compactação do solo, temperatura do solo. 


\section{Introduction}

The increasing and large-scale use of the no-tillage system has enabled the expansion of commercialscale agriculture, requiring more powerful machines, which are normally heavier, in order to obtain higher operational efficiencies and an effective field capacity. This has caused, over time, physical problems in the soil, such as compaction, which reduces soil porosity (Moreira et al., 2014; Mazurana et al., 2017) and, consequently, also reduces the infiltration and storage of water, affecting plant development.

Currently, soil compaction is a frequent and growing problem in agriculture, not only because it reduces crop productivity (Labegalini et al., 2016), but mainly because of the difficultly in measuring it (attributing it a critical value) and confirming it as a factor that decreases production (Gubiani et al., 2015; Mazurana et al., 2017).

Several factors can influence the germination, development, and productivity of crops, such as the level of stored water, nutrients, climate, temperature, and soil factors, as well as the adopted management systems and the equipment used for sowing (Caires \& Milla, 2016; Teixeira et al., 2018). When compared with the outdated double-disk system, for example, the use of a seeder-fertilizer equipped with shanktype furrow openers to break and mobilize the topsoil can minimize some of the problems associated with compaction, by reducing the bulk density of the superficial 15-cm layer (Drescher et al., 2011). Nunes et al. (2014) also reported a reduction in the state of compaction of soil subsuperficial layers during direct sowing using a shank-type furrow opener, which only disrupted part of those layers, providing a similar effect to that produced by the superficial mechanical scarification of the soil.

Palma et al. (2010) carried out a study about the requirement for traction force by shanks set to different soil depths $(10,15,20$, and $25 \mathrm{~cm})$. The authors observed that the lowest demand for force was at the lowest depth, but that the force demanded at $15 \mathrm{~cm}$ was greater than that at $20 \mathrm{~cm}$, because of the greater resistance to penetration at $15 \mathrm{~cm}$. Similarly, Levien et al. (2011) reported an increase of $32 \%$ in the traction force of the shank-type furrow opener, compared with the double-disk type, concluding that this was due to the $52 \%$ larger area of soil mobilized by the shank.
There are many models of combined seedingfertilization machines; however, the used principles are the same. For direct seeding, furrow-opening tools have been developed to deposit fertilizers and seeds, but their effectiveness, which is low for most of them, depends on a series of factors. These factors can be summarized as: soil type; type and format of the furrow opener (shank or disc); speed of the operation together with the used tractor and seeder; quantity, type, and distribution of live or dead vegetation cover on soil surface; presence of subsuperficial roots; level of soil compaction; direction of the operation on inclined surfaces; and soil moisture content at the time of the operation (Levien et al., 2011).

It should be noted that the direct-seeding system is closely linked to other soil characteristics, such as temperature and moisture content. Belan et al. (2014) evaluated the variation in soil temperature related to depth and to the condition of soil cover on a Latossolo Vermelho-Amarelo, i.e., a yellow red latosol, in the state of Espírito Santo, Brazil. The authors found an average thermal amplitude of $5.3^{\circ} \mathrm{C}$ for uncovered soil, at a depth of $2 \mathrm{~cm}$, and of $1.3^{\circ} \mathrm{C}$ for covered ground. This highlights the importance of plant cover to maintain soil temperature close to the physiological optima for plant growth and biological development, by reducing water loss due to direct evaporation. The variation in the temperature of the surface and of the first few centimeters of depth of the soil is directly related to air temperature and soil cover, whereas that of deeper layers depends on intrinsic factors such as soil texture, origin of the material, water content, thermal diffusion, and the level of soil compaction (Prevedello \& Armindo, 2015; Dantas et al., 2017). Other factors, however, such as soil bulk density, also interfere with thermal and soil water content amplitudes. Soils with lower densities present higher thermic amplitudes due to larger air spaces, their lower capacity to conduct heat, and the insulating effect of air (Rodrigues et al., 2018).

In this context, further studies are required to define the efficiency of shank-type tools in breaking compacted soil layers and the soil mobilization caused by them, as well as the effective drawbar power requirements, as pointed out by Conte et al. (2011b).

The objective of this work was to evaluate the impact of different furrow-opening mechanisms on soil physical characteristics, such as soil mobilization, 
porosity, bulk density, and the dynamics of water content and temperature in the sowing groove, as well the influence of wheeled traffic and of these variables on corn productivity.

\section{Materials and Methods}

The study was conducted in the 2014/2015 crop year at the agronomic experimental station of Universidade Federal do Rio Grande do Sul, located at the Depressão Central Depression physiographic region, in the municipality of Eldorado do Sul, in the state of Rio Grande do Sul, Brazil $\left(30^{\circ} 4^{\prime} 38^{\prime \prime} \mathrm{S}\right.$, $\left.51^{\circ} 43^{\prime} 43^{\prime \prime} \mathrm{W}\right)$. The soil of the experimental area is classified as an Argissolo Vermelho-Amarelo (Santos et al., 2013), i.e., a x, naturally characterized as deep, well drained, and strongly acidic, with accumulation of illuvial clay in the B-horizon, low natural fertility, and high saturation by aluminium (Streck et al., 2008). The climate is typical humid subtropical, Cfa according to Köppen's classification, with average monthly temperatures throughout the year varying between 13.9 and $24.9^{\circ} \mathrm{C}$ and an average monthly rainfall from 96 to $168 \mathrm{~mm}$, with a total annual rainfall of 1,440 $\mathrm{mm}$ (Bergamaschi et al., 2003).

The experiment was installed in an area where soybean [Glycine $\max$ (L.) Merr.] improvement programs had been previously carried out by Fundação Estadual de Pesquisa Agropecuária. During this period, the area was intensely prepared through conventional planting, resulting in soil degradation. At the end of the 1970s, the experiment was terminated, and the area was allowed to revert to native vegetation. However, due to the excess of cattle, the area was physically degraded and its botanical composition was altered. From 2002 onwards, an experiment was installed in order to recover the degraded area, using the direct-seeding system.

The experimental design was a randomized complete block, with subdivided plots and four replicates. The main treatments, on $4.5-\mathrm{m}$ wide by $20-\mathrm{m}$ long plots, consisted of: three winter cover crops, i.e., fallow, fodder turnip (Brassica rapa L.), and black oat (Avena strigosa Schreb.) + common vetch (Vicia sativa L.) intercrop; and direct sowing of corn in rotation with soybean in summer. For the experiment, the plots were divided longitudinally in two, allowing two passes of the sower $(2.25 \times 20 \mathrm{~m})$ : one with a straw-cutting disk preceding the shank-type furrow opener and the other with a double disk-type furrow opener.

The Morgan 30A77PW corn hybrid was sown on $12 / 22 / 2014$ at a density of 88 thousand seeds per hectare, fertilized with $250 \mathrm{~kg} \mathrm{ha}^{-1} 5-30-15 \mathrm{~N}-\mathrm{P}_{2} \mathrm{O}_{5}-\mathrm{K}_{2} \mathrm{O}$, respectively. A topdressing of $200 \mathrm{~kg} \mathrm{ha}^{-1}$ urea $(45 \% \mathrm{~N})$ was carried out when the corn reached the V5 stage.

To determine the area of mobilized soil, a 0.35 $\mathrm{m}$ wide profilometer was used, equipped with rods spaced at $0.01 \mathrm{~m}$, with a course (vertical displacement) of $0.35 \mathrm{~m}$. After the manual removal of the mobilized soil from the sowing line, the profilometer rods were released and allowed to form the geometrical shape of the groove, which was copied onto a paper placed on the apparatus. A program using Microsoft Excel calculated the transverse area of the furrow. Further details of the adopted methodology can be found in Conte et al. (2011b).

To obtain the water content of the soil, an auger was used to collect soil samples from the $0-5-, 5-10-, 10-15-$, and $15-20-\mathrm{cm}$ layers. The soil samples were stored in sealed flasks and transported to the laboratory. The samples were then weighed and dried in an oven at $105^{\circ} \mathrm{C}$ until a constant weight was reached, and the gravimetric humidity of each soil layer was determined for the day of collection as described in Claessen (1997).

The surface temperature of the soil was taken using an infrared digital thermometer, while skewer-type digital thermometers were used to record the temperatures at the depths of $3,7,12$, and $17 \mathrm{~cm}$. After the introduction of the thermometer into the soil, $20 \mathrm{~s}$ were allowed for the reading to stabilize before recording the obtained value. Readings were taken during the morning, from 8:30 a.m. to 11:00 a.m., and the afternoon, from 2:30 p.m. to 5:00 p.m., for all plots, and an average was calculated for each period and treatment.

To determine soil bulk density, the volumetric cylinder method was used (Claessen, 1997). Soil samples with preserved structure were collected from the furrow lines to access the layers of 2.0-4.5, 5.0-7.5, $10.0-12.0$, and $15.0-17.5 \mathrm{~cm}$. The samples were then wrapped in plastic film, put into polystyrene boxes, and taken to the soil physics laboratory for analysis.

In order to estimate grain yield, corncobs from the central lines $(20 \mathrm{x} 0.45 \mathrm{~m})$ were harvested manually for each treatment. Subsequently, the samples were mechanically threshed through a stationary thresher, 
the grains were weighed and their water content was corrected to $13 \%$, with results expressed in $\mathrm{Mg} \mathrm{ha}^{-1}$.

The data for the soil and plant variables were compiled and analyzed using the SAS analytical system (SAS Institute Inc., Cary, NC, USA). Means were compared by the F-test and, when significant, Tukey's test was applied at 5\% probability.

\section{Results and Discussion}

The treatments involving soil cover with winter crops did not influence the obtained results. The higher mobilization of the soil in the furrow using the shank-type furrow opener was due to a greater depth of penetration (Figure 1). Conte et al. (2011a) found an increment of $107 \%$ in the area of mobilized soil in the furrow with the increase of the depth of action of the shank-type furrow opener, from 6 to 12 $\mathrm{cm}$, confirming the data found in the present study. However, the relationship depth/area of mobilization is limited by the critical depth of action of the shank, given by the format and angle of attack of the tip of the tool and defined by Spoor \& Godwin (1978) as the depth at which the tractive effort increases, without there being a significant increase in soil mobilization.

Conte et al. (2011b) tested the ability of a shank-type furrow opener to open deeper furrows in an Ultisol

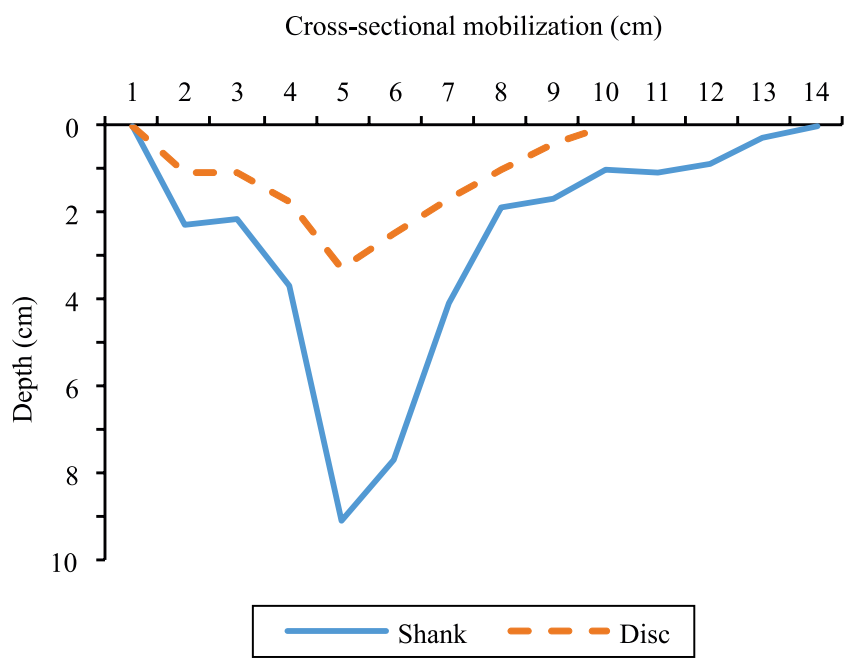

Figure 1. Cross-sectional mobilization against depth to compare the roles of the different types of furrow openers used for sowing and fertilization. and observed an increase in the mobilized area when depth increased from 6 to $9 \mathrm{~cm}$, but stability at $12 \mathrm{~cm}$. However, when depth was increased from 12 to 15 $\mathrm{cm}$, there was a reduction in the mobilized area; this occurred because the critical depth for this particular shank-type tool had been exceeded.

Moreover, the greater capacity of deep furrowopening tools, such as the shank-type ones, favors the breaking of compacted layers, both on soil surface and subsurface in no-tillage systems. This improves soil physical characteristics, besides favouring nutrient distribution through the soil profile, providing conditions for deeper root growth (Nunes et al., 2014), which could be beneficial in the case of short periods of drought.

Soil water content showed temporal variation during the crop cycle (Figure 2), mainly due to the soil wetting and drying cycles, dependent on factors such as precipitation and dry periods, besides a higher or lower demand by the crop during its development, with no significant differences between treatments. Furlani et al. (2008) reported that soil cover has a great influence on soil water content, which could possibly explain why no differences were observed within the same evaluation period. The volumetric moisture values obtained were below those reported by Sequinatto et al. (2014) for field capacity of the same soil: $0.28 \mathrm{~m}^{3} \mathrm{~m}^{-3}$ for locations with wheeled traffic and $0.26 \mathrm{~m}^{3} \mathrm{~m}^{-3}$ for those with no traffic. This suggests that the corn crop did in fact need the soil to be at full field capacity to express its maximum productive potential.

Soil temperature was registered in the morning and the afternoon, respectively, during the corn development cycle (Figures 3 and 4). The highest temperatures were observed at the first evaluation time, when the corn crop had not yet covered the soil surface, which is associated with the low quantity of crop residues left in winter, resulting in a high exposure of the soil to solar radiation.

Contrary to the central hypothesis of the present study, the nonsignificant differences regarding soil temperatures may be explained by the use of the notillage system in all treatments. This corroborates, in part, the results of Furlani et al. (2008), who found differences in soil temperatures due to the preparation and/or cover of the soil. These authors concluded that the no-tillage system always presented the lowest thermic amplitude, compared with other preparation 
systems such as the conventional and scarified ones. These studies also showed that, independently of the type of soil preparation, soil temperature did not differ between treatments when the plants provided more than $50 \%$ soil coverage.

The temperature variations observed in the more superficial soil layers are mainly affected by soil texture and structure, besides being directly related to ionic exchanges between the root system and the soil; however, they are also influenced by the soil management system (Bergamaschi et al., 2010; Veiga et al., 2010; Montanari et al., 2012). Under the no-tillage system, for example, plant cover has an important role in the dynamics of soil temperature, and the main problems related to soil temperature and nutrients refer to their solubility (Grant et al., 2001).

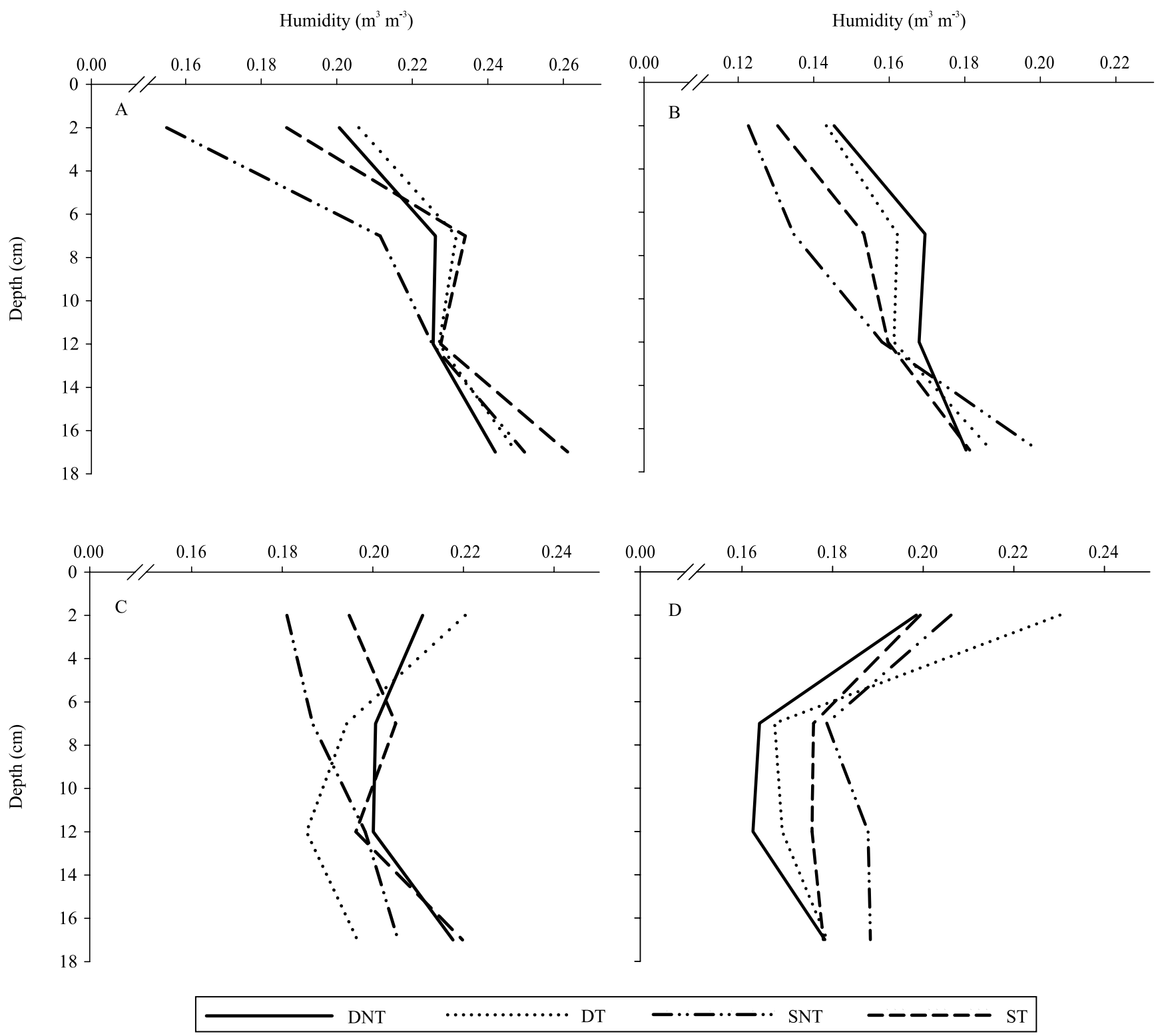

Figure 2. Soil water content throughout the corn (Zea mays) crop cycle under different soil mobilization systems, machine traffic conditions, and soil layers. DNT, disc with no traffic; DT, disc with traffic; SNT, shank with no traffic; and ST, shank with traffic. 
A significant difference in bulk density and macroporosity was found between the different types of furrow openers (Table 1): the shank-type furrow opener presented a lower bulk density in the $0.00-0.05-$ $\mathrm{m}$ layer and a higher macroporosity in the $0.05-0.10$ $\mathrm{m}$ layer, which can be attributed to the greater depth achieved by this type of furrow opener in relation to double discs (Figure 1). Despite this difference, the values for macroporosity are not considered critical because they are above $0.1 \mathrm{~m}^{3} \mathrm{~m}^{-3}$, the limit for gaseous porosity according to Tormena et al. (1998), which would restrict plant development by limiting gas exchange. However, it should be pointed out that, as the evaluations were carried out at the end of the crop cycle, there may have been a natural densification of the soil particles in the surface layer, reducing the difference between the effects of the furrowers.

Furthermore, because the shank-type furrow opener was used since the adoption of the no-tillage system to sow the summer crops in the experimental area, there may have been a residual effect from the previous crop cycles, reducing the chances of observing differences

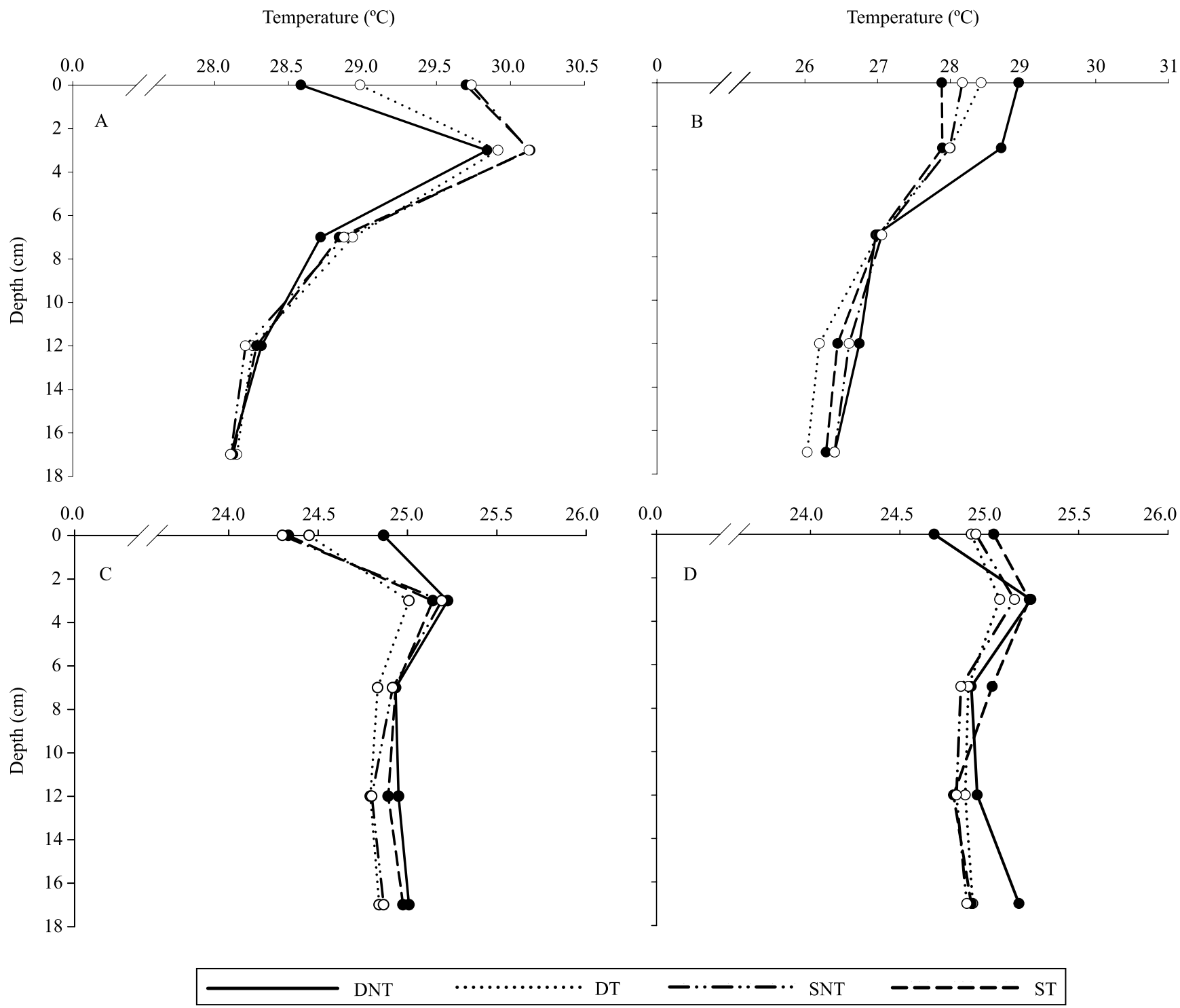

Figure 3. Soil temperature in the morning, depending on the type of furrow opener used, machine traffic conditions, and soil depth, during the corn (Zea mays) crop cycle at: A, 15 days after emergence (DAE); B, 29 DAE; C, 38 DAE; and D, 46 DAE. DNT, disc with no traffic; DT, disc with traffic; SNT, shank with no traffic; and ST, shank with traffic. No significant difference by Tukey's test, at $5 \%$ probability. 
in these variables (Nunes et al., 2014). When studying the action of a shank-type furrow opener at the depths of 10,15 , and $17 \mathrm{~cm}$ of a Latossolo Vermelho, i.e., a Haplorthox, the authors found a residual effect of the tool on soil mobilization after 12 months, supporting the raised hypothesis.

No significant differences were observed in corn productivity between the types of winter cover crops or between the types of furrow opener used (Table 2). However, there were significant differences between the different traffic conditions using the same furrow opener, mainly because traffic had a negative effect on grain production, especially when sowing was carried out using the disk-type furrow opener. The obtained corn productivity could be considered low compared with those of crops grown under hightechnology systems. A possible explanation is the high temperature during the early stages of development of the corn crop, which may have influenced its germination and initial establishment, as well as the water deficit that occurred during the critical phases of crop development.
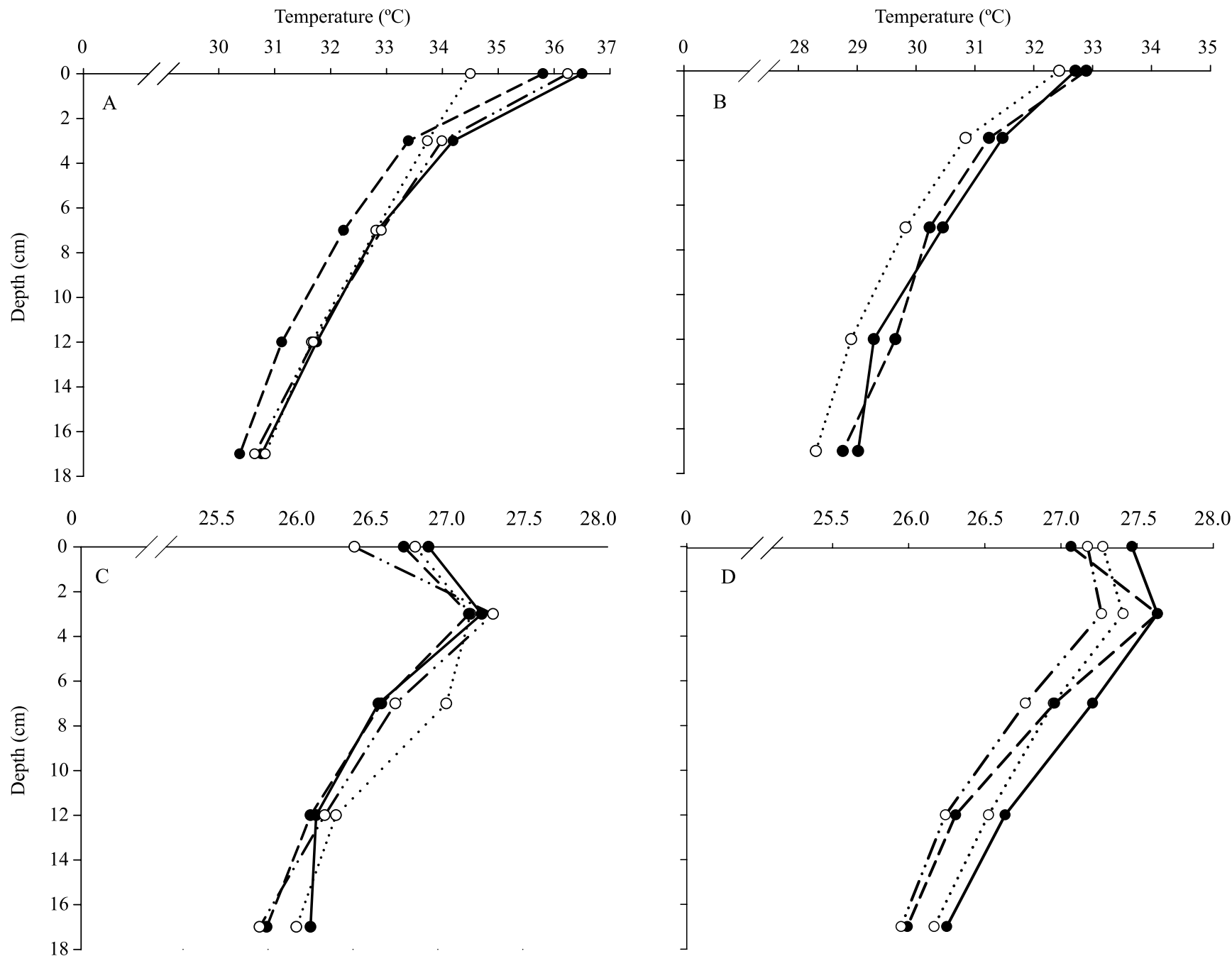

DNT

$\cdots \cdots \cdots \cdots \cdots \cdot$ DT

SNT

- - - - ST

Figure 4. Soil temperature in the afternoon, depending on the type of furrow opener used, machine traffic conditions, and soil depth, during the corn (Zea mays) crop cycle at: 15 days after emergence (DAE); B, 29 DAE; C, 38 DAE; and D, 46 DAE. DNT, disc with no traffic; DT, disc with traffic; SNT, shank with no traffic; and ST, shank with traffic. No significant difference by Tukey's test, at $5 \%$ probability. 
Table 1. Bulk density, macroporosity, microporosity, and total porosity at different soil depths due to the type of furrow opener used and wheeled traffic during sowing and fertilization $^{(1)}$.

\begin{tabular}{|c|c|c|c|c|c|}
\hline \multirow[t]{2}{*}{ Furrower } & \multirow[t]{2}{*}{ Traffic } & \multicolumn{4}{|c|}{ Layer (m) } \\
\hline & & $0.00-0.05$ & $0.05-0.10$ & $0.10-0.15$ & $0.15-0.20$ \\
\hline & & & density ( $\mathrm{N}$ & $\left.\mathrm{m}^{-3}\right)$ & \\
\hline \multirow{2}{*}{ Disc } & Without & $1.29 \mathrm{~b}$ & $1.44 \mathrm{a}$ & $1.47 \mathrm{a}$ & $1.61 \mathrm{a}$ \\
\hline & With & $1.40 \mathrm{a}$ & $1.50 \mathrm{a}$ & $1.52 \mathrm{a}$ & $1.62 \mathrm{a}$ \\
\hline \multirow{2}{*}{ Shank } & Without & $1.2 \mathrm{~b}$ & $1.41 \mathrm{a}$ & $1.52 \mathrm{a}$ & $1.59 \mathrm{a}$ \\
\hline & With & $1.29 \mathrm{a}$ & $1.46 \mathrm{a}$ & $1.50 \mathrm{a}$ & $1.65 \mathrm{a}$ \\
\hline & \multicolumn{5}{|c|}{ Macroporosity $\left(\mathrm{m}^{3} \mathrm{~m}^{-3}\right)$} \\
\hline \multirow{2}{*}{ Disc } & Without & $0.24 \mathrm{a}$ & $0.16 \mathrm{a}$ & $0.15 \mathrm{a}$ & $0.12 \mathrm{a}$ \\
\hline & With & $0.18 \mathrm{~b}$ & $0.14 \mathrm{a}$ & $0.16 \mathrm{a}$ & $0.11 \mathrm{a}$ \\
\hline \multirow{2}{*}{ Shank } & Without & $0.27 \mathrm{a}$ & $0.20 \mathrm{a}$ & $0.17 \mathrm{a}$ & $0.14 \mathrm{a}$ \\
\hline & With & $0.23 b$ & $0.19 \mathrm{a}$ & $0.17 \mathrm{a}$ & $0.11 \mathrm{a}$ \\
\hline & \multicolumn{5}{|c|}{ Microporosity $\left(\mathrm{m}^{3} \mathrm{~m}^{-3}\right)$} \\
\hline \multirow{2}{*}{ Disc } & Without & $0.27^{\mathrm{ns}}$ & 0.33 & 0.27 & 0.27 \\
\hline & With & 0.29 & 0.33 & 0.27 & 0.27 \\
\hline \multirow{3}{*}{ Shank } & Without & 0.26 & 0.33 & 0.26 & 0.28 \\
\hline & With & 0.26 & 0.31 & 0.27 & 0.27 \\
\hline & \multicolumn{5}{|c|}{ Total porosity $\left(\mathrm{m}^{3} \mathrm{~m}^{-3}\right)$} \\
\hline \multirow{2}{*}{ Disco } & Without & $0.50^{\text {ns }}$ & 0.48 & 0.43 & 0.39 \\
\hline & With & 0.46 & 0.46 & 0.43 & 0.38 \\
\hline \multirow{2}{*}{ Shank } & Without & 0.52 & 0.50 & 0.43 & 0.42 \\
\hline & With & 0.48 & 0.50 & 0.43 & 0.38 \\
\hline
\end{tabular}

${ }^{(1)}$ Means followed by equal letters, uppercase in the rows and lowercase in the columns, within the same attribute, do not differ by Tukey's test, at $5 \%$ probability.

Table 2. Grain productivity of the corn (Zea mays) crop in the 2014/2015 harvest due to the use of two types of furrow openers and to tractor traffic during sowing and fertilization $^{(1)}$.

\begin{tabular}{|c|c|c|c|}
\hline Furrower & Traffic & Productivity $\left(\mathrm{Mg} \mathrm{ha}^{-3}\right)$ & Mean \\
\hline \multirow{2}{*}{ Disc } & Without & $5.82 \mathrm{a}$ & \multirow{2}{*}{$4.84 \mathrm{~A}$} \\
\hline & With & $3.85 b$ & \\
\hline \multirow{2}{*}{ Shank } & Without & $5.43 \mathrm{a}$ & \multirow{2}{*}{$5.38 \mathrm{~A}$} \\
\hline & With & $5.34 \mathrm{a}$ & \\
\hline
\end{tabular}

(1)Means followed by equal letters, lowercase in the column comparing the traffic for each type of furrow opener and uppercase in the column comparing the two types of furrow openers, do not differ by Tukey's test, at $5 \%$ probability.
When the double-disk furrow opener was used in the absence of wheeled traffic over the sowing groove, corn productivity was $34 \%$ higher than that obtained with traffic. This was due to a series of negative factors observed during the evaluations, such as an increase in soil bulk density in the superficial layers that could hinder the development of the crop root system. Beutler et al. (2009) reported a reduction of up to $22 \%$ in corn productivity due to soil compaction caused by machine traffic, while Girardello et al. (2014) observed a drop in production of $24 \%$ under machine traffic. In an experiment with common bean (Phaseolus vulgaris L.), Collares et al. (2008) found that the growth of the root system and of the shoots of the crop, as well as productivity, was lower in locations with additional compaction.

\section{Conclusions}

1. The shank-type furrow opener promotes a higher mobilization of the soil in the sowing groove and an increase in macroporosity in the $0.0-0.05-\mathrm{m}$ superficial layer.

2. The type of furrow opener (shank or disc) does not influence temperature or moisture dynamics in the sowing groove.

3. Machine traffic results in lower corn (Zea mays) productivity when the disk-type furrow opener is used.

\section{Acknowledgments}

To Faculdade de Agronomia of Universidade Federal do Rio Grande do Sul (UFRGS), for the opportunity to carry out this study; and to Conselho Nacional de Desenvolvimento Científico e Tecnológico (CNPq), for scholarship.

\section{References}

BELAN, L.L.; XAVIER, T.M.T.; TORRES, H.; TOLEDO, J.V.; PEZZOPANE, J.E.M. Dinâmica entre temperaturas do ar e do solo sob duas condições de cobertura. Revista Academica: Ciências Agrárias e Ambientais, v.11, p.S147-S154, 2014. Suplemento 1. DOI: https://doi.org/10.7213/academica.10.s01.ao17.

BERGAMASCHI, H.; DALMAGO, G.A.; BERGONCI, J.I.; KRÜGER, C.A.M.B.; HECKLER, B.M.M.; COMIRAN, F. Intercepted solar radiation by maize crops subjected to different tillage systems and water availability levels. Pesquisa Agropecuária Brasileira, v.45, p.1331-1341, 2010. DOI: https:// doi.org/10.1590/S0100-204X2010001200001. 
BERGAMASCHI, H.; GUADAGNIN, M.R.; CARDOSO, L.S.; SILVA, M.I.G. da. Clima da Estação Experimental da UFRGS (e região de abrangência). Porto Alegre: UFRGS, 2003. 77p.

BEUTLER, A.N.; CENTURION, J.F.; MENGATTO, L.H.; MENGATTO, L.H.; ALVES, J.B.; WAGNER, G.P.C. Impacto do tráfego de máquinas na qualidade física do solo e produtividade de milho em Argissolo. Acta Scientiarum. Agronomy, v.31, p.359364, 2009. DOI: https://doi.org/10.4025/actasciagron.v31i2.7042.

CAIRES, E.F.; MILLA, R. Adubação nitrogenada em cobertura para o cultivo de milho com alto potencial produtivo em sistema de plantio direto de longa duração. Bragantia, v.75, p.87-95, 2016.

CLAESSEN, M.E.C. (Org.). Manual de métodos de análise de solo. 2.ed. rev. e atual. Rio de Janeiro: Embrapa-CNPS, 1997. 212p.

COLLARES, G.L.; REINERT, D.J.; REICHERT, J.M.; KAISER, D.R. Compactação de um latossolo induzida pelo tráfego de máquinas e sua relação com o crescimento e produtividade de feijão e trigo. Revista Brasileira de Ciência do Solo, v.32, p.933-942, 2008. DOI: https://doi.org/10.1590/S0100-06832008000300003.

CONTE, O.; FLORES, J.P.C.; CASSOL, L.C.; ANGHINONI, I.; CARVALHO, P.C. de F.; LEVIEN, R.; WESP, C. de L. Evolução de atributos físicos de solo em sistema de integração lavourapecuária. Pesquisa Agropecuária Brasileira, v.46, p.1301-1309, 2011a. DOI: https://doi.org/10.1590/S0100-204X2011001000026.

CONTE, O.; LEVIEN, R.; DEBIASI, H.; STÜRMER, S.L.K.; MAZURANA, M.; MÜLLER, J. Soil disturbance index as an indicator of seed drill efficiency in no-tillage agrosystems. Soil \& Tillage Research, v.114, p.37-42, 2011b. DOI: https://doi. org/10.1016/j.still.2011.03.007.

DANTAS, D.; BARBOSA, G.P.; CUNHA, E.G.S.; SOUZA, M.J.H. de; SOUZA, C.M.P. de. Temperatura do ar e do solo em diferentes profundidades, em Diamantina - MG. Caderno de Ciências Agrárias, v.9, p.61-66, 2017.

DRESCHER, M.S.; ELTZ, F.L.F.; DENARDIN, J.E.; FAGANELlO, A. Persistência do efeito de intervenções mecânicas para a descompactação de solos sob plantio direto. Revista Brasileira de Ciência do Solo, v.35, p.1713-1722, 2011. DOI: https://doi.org/10.1590/S0100-06832011000500026.

FURLANI, C.E.A.; GAMERO, C.A.; LEVIEN, R.; SILVA, R.P. da; CORTEZ, J.W. Temperatura do solo em função do preparo do solo e do manejo da cobertura de inverno. Revista Brasileira de Ciencia do Solo, v.32, p.375-380, 2008. DOI: https://doi. org/10.1590/S0100-06832008000100035.

GIRARDELLO, V.C.; AMADO, T.J.C.; SANTI, A.L.; CHERUBIN, M.R.; KUNZ, J.; TEIXEIRA, T. de G. Resistência à penetração, eficiência de escarificadores mecânicos e produtividade da soja em Latossolo argiloso manejado sob plantio direto de longa duração. Revista Brasileira de Ciência do Solo, v.38, p.1234-1244, 2014. DOI: https://doi.org/10.1590/S010006832014000400020.

GRANT, C.A.; FLATEN, D.N.; TOMASIEWICZ, D.J.; SHEPPARD, S.C. A importância do fósforo no desenvolvimento inicial da planta. Informações Agronômicas, n.95, 2001.

GUBIANI, P.I.; LIER, Q. de J. van; DRESCHER, M.S.; MEZZOMO, H.C.; VEIGA, C.M.C. Relação entre densidade do solo e conteúdo de água em repetidos ciclos de contração e expansão em um Latossolo. Revista Brasileira de Ciencia do Solo, v.39, p.100-108, 2015. DOI: https://doi. org/10.1590/01000683rbcs20150317.

LABEGALINI, N.S.; BUCHELT, A.C.; ANDRADE, L.; OLIVEIRA, S.C. de; CAMPOS, L.M. Desenvolvimento da cultura do milho sob efeitos de diferentes profundidades de compactação do solo. Revista de Agricultura Neotropical, v.3, p.7-11, 2016. DOI: https://doi.org/10.32404/rean.v3i4.1102.

LEVIEN, R.; FURLANI, C.E.A.; GAMERO, C.A.; CONTE, O.; CAVICHIOLI, F.A. Semeadura direta de milho com dois tipos de sulcadores de adubo, em nível e no sentido do declive do terreno. Ciência Rural, v.41, p.1003-1010, 2011. DOI: https://doi. org/10.1590/s0103-84782011000600014.

MAZURANA, M.; LEVIEN, R.; ZULPO, L.; PASSOS, G.M.; KERPEN, H.S. Dynamic of pressure-deformation curve in uniaxial compression test in different load times. Engenharia Agrícola, v.37, p.973-986, 2017. DOI: https://doi.org/10.1590/18094430-Eng.Agric.v37n5p973-986/2017.

MONTANARI, R.; ZAMBIANCO, E.C.; CORREAA, A.R.; PELLIN, D.M.P.; CARVALHO, M. de P. e; DALCHIAVON, F.C. Atributos físicos de um Latossolo Vermelho correlacionados linear e espacialmente com a consorciação de guandu com milheto. Revista Ceres, v.59, p.125-135, 2012. DOI: https://doi. org/10.1590/S0034-737X2012000100018.

MOREIRA, W.H.; TORMENA, C.A.; BETIOLI JUNIOR, E.; PETEAN, L.P.; ALVES, S.J. Influência da altura de pastejo de azevém e aveia em atributos físicos de um Latossolo Vermelho distroférrico, após sete anos sob integração lavoura-pecuária. Revista Brasileira de Ciência do Solo, v.38, p.1315-1326, 2014. DOI: https://doi.org/10.1590/S0100-06832014000400027.

NUNES, M.R.; DENARDIN, J.E.; FAGANELLO, A.; PAULETTO, E.A.; PINTO, L.F.S. Efeito de semeadora com haste sulcadora para ação profunda em solo manejado com plantio direto. Revista Brasileira de Ciência do Solo, v.38, p.627-638, 2014. DOI: https://doi.org/10.1590/S0100-06832014000200027.

PALMA, M.A.Z.; VOLPATO, C.E.S.; BARBOSA, J.A.; SPAGNOLO, R.T.; BARROS, M.M. de; VILAS BOAS, L. do A. Efeito da profundidade de trabalho das hastes sulcadoras de uma semeadora-adubadora na patinagem, na força de tração e no consumo de combustível de um trator agrícola. Ciência e Agrotecnologia, v.34, p.1320-1326, 2010. DOI: https://doi. org/10.1590/S1413-70542010000500034.

PREVEDELLO, C.L.; ARMINDO, R.A. Física do solo: com problemas resolvidos. 2.ed. rev. e ampl. Curitiba: C.L. Prevedello, 2015. 474p.

RODRIGUES, G.A.; SANTOS, G.O.; CARRASQUEIRA, A.; MACHADO, E.R.; ASSIRATI, E.T.; MACRI, R. de C.V. Oscilações da temperatura do solo em função de quantidades de palha e horários ao longo do dia. Revista Interface Tecnológica, v.15, p.293-304, 2018. DOI: https://doi.org/10.31510/infa.v15il.353.

SANTOS, H.G. dos; JACOMINE, P.K.T.; ANJOS, L.H.C. dos; OLIVEIRA, V.A. de; LUMBRERAS, J.F.; COELHO, M.R.; ALMEIDA, J.A. de; CUNHA, T.J.F.; OLIVEIRA, J.B. de. 
Sistema brasileiro de classificação de solos. 3.ed. rev. e ampl. Brasília: Embrapa, 2013. 353p.

SEQUINATTO, L.; LEVIEN, R.; TREIN, C.R.; MAZURANA, M.; MÜLLER, J. Qualidade de um Argissolo submetido a práticas de manejo recuperadoras de sua estrutura física. Revista Brasileira de Engenharia Agrícola e Ambiental, v.18, p.344-350, 2014. DOI: https://doi.org/10.1590/s1415-43662014000300015.

SPOOR, G.; GODWIN, R.J. An experimental investigation into the deep loosening of soil by rigid tines. Journal of Agricultural Engineering Research, v.23, p.243-258, 1978. DOI: https://doi. org/10.1016/0021-8634(78)90099-9.

STRECK, E.V.; KAMPF, N.; DALMOLIN, R.S.D.; KLAMT, E.; NASCIMENTO, P.C. do; SCHNEIDER, P.; PINTO, L.F.S. Solos do Rio Grande do Sul. 2.ed. rev. e ampl. Porto Alegre: UFRGS: EMATER/RS-ASCAR, 2008. 222p.
TEIXEIRA, H.R.S.; LIMA, E. de A.; MIELEZRSKI, F.; SILVA, A.F. da; OLIVEIRA, A.M. de. Efeito da profundidade de adubação e semeadura na cultura do milho. Cultura Agronômica, v.27, p.91-100, 2018.

TORMENA, C.A.; SILVA, A.P.; LIBARDI, P.L. Caracterização do intervalo hídrico ótimo de um Latossolo Roxo sob plantio direto. Revista Brasileira de Ciência do Solo, v.22, p.573-581, 1998. DOI: https://doi.org/10.1590/S0100-06831998000400002.

VEIGA, M. da; REINERT, D.J.; REICHERT, J.M. Tillage systems and nutrient sources affecting soil cover, temperature and moisture in a clayey Oxisol under corn. Revista Brasileira de Ciência do Solo, v.34, p.2011-2020, 2010. DOI: https://oi. org/10.1590/s0100-06832010000600025. 